\title{
PENGARUH LINGKUNGAN KERJA NON FISIK DAN KETERLIBATAN ORGANISASIONAL TERHADAP RETENSI KARYAWAN
}

\author{
Desak Made Yuni Astuti ${ }^{1}$ \\ A.A. Sagung Kartika Dewi \\ ${ }^{1,2}$ Fakultas Ekonomi dan Bisnis Universitas Udayana (Unud), Bali, Indonesia \\ e-mail: desakyuni10@yahoo.com
}

\begin{abstract}
ABSTRAK
Tujuan penelitian ini adalah untuk mengetahui pengaruh lingkungan kerja non fisik dan keterlibatan organisasional terhadap retensi karyawan. Penelitian ini dilakukan di Hotel Kumala Pantai Legian. Populasi penelitian ini adalah seluruh karyawan tetap yang berjumlah 148 orang dan menggunakan rumus slovin untuk memperoleh sampel sebanyak 108 reponden. Teknik penentuan sampel yang digunakan pada penelitian ini adalah disproportionate stratified random sampling. Metode pengumpulan data dilakukan dengan cara wawancara dan survey dengan alat bantu berupa kuisioner. Teknik analisis data yang digunakan adalah analisis regresi linear berganda yang diolah menggunakan SPSS. Hasil penelitian ini menunjukan bahwa seluruh hipotesis penelitian dapat diterima. Lingkungan kerja non fisik berpengaruh positif dan signifikan terhadap retensi karyawan. Keterlibatan organisasional berpengaruh positif dan signifikan terhadap retensi karyawan. Semakin baik lingkungan kerja non fisik dan keterlibatan organisasional, maka tingkat retensi karyawan semakin tinggi.
\end{abstract}

Kata Kunci: lingkungan kerja non fisik, keterlibatan organisasional, retensi karyawan

\section{ABSTRACT}

The purpose of this study was to determine the effect of non-physical work environment and organizational involvement on employee retention. This research was conducted at Kumala Hotel Legian Beach. The population of this study was all permanent employees totaling 148 people and using the Slovin formula to obtain a sample of 108 respondents. The sampling technique used in this study is disproportionate stratified random sampling. The method of data collection is done by means of interviews and surveys with tools in the form of questionnaires. The data analysis technique used is multiple linear regression analysis which is processed using SPSS. The results of this study indicate that all research hypotheses are acceptable. Non-physical work environment has a positive and significant effect on employee retention. Organizational involvement has a positive and significant effect on employee retention. The better the non physical work environment and organizational involvement, the higher the employee retention rate.

Keywords: non physical work environment, organizational involvement, employee retention 


\section{PENDAHULUAN}

Pulau Bali telah dikenal sebagai salah satu destinasi tujuan wisata yang ada di Indonesia. Keindahan alam, budaya, adat istiadat yang masih sangat kental mampu menjadi daya tarik bagi wisatawan lokal maupun mancanegara untuk berwisata ke Pulau Bali. Kunjungan wisatawan ini dapat menjadikan bisnis di bidang pariwisata semakin menjanjikan khusunya dalam bidang perhotelan. Hal ini menyebabkan perusahaan di bidang perhotelan berusaha untuk bersaing satu sama lain untuk memperoleh keuntungan yang sebesar-besarnya, oleh karena itu perusahaan harus memiliki daya saing yang tinggi, manajemen yang baik dan sumber daya yang berkualitas.

Menurut Putra dan Ardana (2016) sumber daya manusia (SDM) merupakan sumber daya terpenting yang harus dimiliki perusahaan. Keberhasilan dan keefektivan suatu perusahaan sangat bergantung pada kinerja dan kualitas dari SDM yang ada pada perusahaan tersebut (Darmawati dkk., 2013). Sumber daya manusia memiliki pengaruh dalam perkembangan perusahaan serta memiliki peran penting dalam aktivitas perusahaan (Mustika, 2012). Menurut Cao et al. (2013), perusahaan perlu memperhatikan kesejahteraan karyawan agar karyawan tetap bekerja dengan baik. Ahmed dan Uddin (2012) menyatakan bahwa keberhasilan suatu perusahaan dapat dilihat dari bagaimana kinerja, ketekunan, efisiensi, kejujuran dan integritas dari karyawannya.

Kegagalan perusahaan dalam mengelola sumber daya manusia, menyebabkan adanya hambatan dalam pencapaian tujuan organisasi, baik dalam kinerja, profit, maupun kelangsungan hidup dari perusahaan itu sendiri (Rayadi, 2012). Perusahaan 
yang mengalami kegagalan dalam mengelola sumber daya manusia dapat memicu keinginan karyawan untuk keluar dari perusahaan, hal ini tentu saja dapat memperburuk kondisi perusahaan. Menurut Das dan Baruah (2013) hal yang dapat menjadi kunci kesuksesan dan kesehatan jangka panjang suatu organisasi adalah kemampuan organisasi dalam mempertahankan karyawan potensialnya atau disebut juga sebagai retensi karyawan.

Berdasarkan teori pertukaran sosial (Social Exchange Theory) yang dikemukakan oleh Blau (1964), menyatakan pertukaran sosial mengacu pada tindakan sukarela individu yang dimotivasi oleh harapan pengembalian atau imbalan yang biasanya diterima dari orang lain. Fung et al. (2012) menyatakan bahwa pertukaran sosial dapat terjadi ketika antara pihak karyawan dengan pihak organisasi bisa memberikan sesuatu yang dianggap menguntungkan bagi kedua pihak dan didasari oleh kepercayaan. Berdasarkan penelitian yang dilakukan oleh Kundu dan Lata (2017), teori pertukaran sosial mampu membentuk komponen dari lingkungan kerja yang baik di dalam perusahaan, yang nantinya mampu menumbuhkan retensi karyawan.

Retensi karyawan merupakan kebijakan perusahaan dalam mempertahankan loyalitas karyawan potensial pada perusahaan (Astuti dan Panggabean, 2014). Jennifer (2005:2) mengemukakan bahwa retensi karyawan adalah salah satu cara manajemen untuk mempertahankan karyawan yang kompeten pada jangka waktu tertentu. Menurut Susilo (2013), retensi karyawan mengacu pada keinginan karyawan untuk bertahan di suatu perusahaan dalam jangka waktu yang lama. 
Retensi karyawan mengarah pada teknik manajemen yang digunakan untuk membuat karyawan bertahan dengan organisasi dalam jangka waktu yang lama (Ragupathi, 2013). Menurut Hafanti dkk. (2015), retensi karyawan adalah keahlian perusahaan dalam mempertahankan karyawan terbaik yang dimiliki agar terus berada di dalam perusahaan. Menurut Fatima (2011), tercapainya visi dan misi perusahaan dipengaruhi oleh tingkat retensi karyawan.

Gberevibe (2008) menyatakan bahwa perusahaan yang mampu mengimplementasikan strategi retensi dengan baik, menyebabkan karyawan akan melakukan hal yang terbaik untuk mencapai keberhasilan perusahaan. Rendahnya retensi karyawan, mengakibatkan tingginya tingkat turnover yang memiliki hubungan negatif terhadap efektivitas dan kinerja perusahaan (Putra dan Rahyuda, 2016). Perusahaan yang tidak dapat mempertahankan karyawannya, akan menyianyiakan investasi dalam sumber daya manusia (Sari dan Sinulingga, 2011). Menurut Dess dan Shaw (2001), pergantian karyawan lama dengan karyawan baru menyebabkan adanya peningkatan biaya operasional dalam bentuk pelatihan karyawan.

Salah satu faktor yang mempengaruhi retensi karyawan adalah lingkungan kerja (Ghosh et al., 2013). Lingkungan kerja merupakan keadaan di sekitar tempat kerja baik secara fisik maupun non fisik yang dapat memberikan perasaan senang, aman dan tentram bagi karyawan (Supardi, 2003:37). Menurut Nitisemito (2006:109), lingkungan kerja merupakan suatu keadaan yang ada di sekitar karyawan yang dapat mempengaruhi karyawan dalam menjalankan suatu pekerjaan. Widodo (2014) menyatakan bahwa lingkungan kerja merupakan sesuatu 
yang berada di lingkungan eksternal organisasi yang memiliki pengaruh terhadap kinerja karyawan dan menentukan kinerja dari organisasi.

Lingkungan kerja adalah suatu keadaan atau tempat yang memberikan rasa nyaman dan aman untuk karyawan melakukan aktivitas kerjanya dengan baik, yang nantinya dapat menentukan keberhasilan suatu perusahaan (Putra dan Rahyuda, 2016). Menurut Sedarmayanti (2011:26), lingkungan kerja dapat dibedakan menjadi dua jenis yaitu lingkungan kerja fisik seperti lingkungan tempat kerja dan lingkungan kerja non fisik seperti suasana kerja dalam suatu perusahaan. Perusahaan perlu menciptakan lingkungan kerja yang baik secara fisik maupun non fisik untuk membantu perusahaan dalam mencapai tujuannya (Rahmawanti dkk., 2014).

Penelitian ini lebih menekankan variabel lingkungan kerja non fisik, hal ini dikarenakan lingkungan kerja non fisik memiliki kaitan yang erat dengan hubungan karyawan dengan atasan maupun rekan kerja, tingkat kesejahteraan terutama manfaat non tunai dan faktor yang berkaitan dengan tempat kerja (Taiwo, 2010). Menurut Wursanto (2009:269), karyawan dapat merasakan lingkungan kerja non fisik melalui hubungan karyawan dengan atasan maupun sesama rekan kerja. Perusahaan yang menciptakan lingkungan kerja non fisik yang baik, kenyamanan dan keamanan ruang kerja dan komunikasi yang efektif dapat meningkatkan retensi karyawan (Kwenin, 2013).

Faktor lain yang mempengaruhi retensi karyawan adalah keterlibatan organisasional (Kundu dan Lata, 2017). Keterlibatan organisasional merupakan penguasaan diri anggota organisasi terhadap peran pekerjaannya (Kahn, 1990). 
Menurut Indayati dkk. (2012) keterlibatan organisasional merupakan sejauh mana seorang karyawan memusatkan perhatian dan emosi dalam melakukan pekerjaanya di perusahaan. Sirisunhirun dan Dhirathiti (2015) mengatakan bahwa keterlibatan organisasional merupakan komitmen emosional dan intelektual seorang karyawan terhadap perusahaan. Keterlibatan organisasional menekankan pada identifikasi kebutuhan karyawan yang secara strategis digabungkan dengan budaya organisasi (Nutov dan Hazzan, 2014). Menurut Glen (2006), perusahaan menggunakan keterlibatan organisasional sebagai salah satu strategi untuk mempertahankan karyawan yang kompeten yang dimiliki perusahaan.

Schaufeli et al. (2002), menyatakan bahwa keterlibatan merupakan keadaan positif dalam pekerjaan yang ditandai dengan adanya kekuatan, dedikasi dan penyerapan. Menurut Rothbard (2001), keterlibatan adalah suatu keadaan psikologis yang di dalamnya terdapat dua komponen penting, yaitu perhatian dan penyerapan. Malinen et al. (2013) menyatakan bahwa keterlibatan organisasional ditandai oleh adanya kekuatan, keterkaitan antara karyawan dengan organisasi dan keberhasilan dalam suatu organisasi. Menurut Harter et al. (2002) keterlibatan merupakan hasil dari komitmen organisasi yang lebih kuat, kepuasan kerja yang lebih besar dan lingkungan kerja yang lebih baik.

Saks (2006) menyatakan bahwa salah satu indikator dari adanya pergantian karyawan adalah keterlibatan organisasional. Menurut Schaufeli dan Bakker (2004), keterlibatan organisasional berperan sebagai perantara hubungan antara sumber kerja dengan turnover intention. Berdasarkan penelitian yang dilakukan oleh Lockwood (2007), keterlibatan organisasional memiliki pengaruh terhadap 
retensi karyawan dan kesuksesan perusahaan. Keterlibatan organisasional berperan penting bagi hasil kerja karyawan yang dapat menumbuhkan retensi karyawan (Juhdi et al., 2013).

Penelitian ini dilakukan di Hotel Kumala Pantai Legian yang terletak di Jalan Werkudara, Legian, Kuta, Badung-Bali. Hotel Kumala Pantai Legian yang berdiri pada tahun 2002 ini merupakan salah satu penyedia jasa penginapan di Kuta dengan standar bintang tiga. Fasilitas yang dimiliki Hotel Kumala Pantai Legian ini meliputi 153 kamar tidur, 4 apartement, restoran, kolam renang, salon \& spa dan drugstore. Hotel Kumala Pantai Legian masih terus melakukan inovasi-inovasi guna mengembangkan bisnisnya agar mampu bersaing dan memenuhi permintaan di pasar global saat ini.

Berdasarkan hasil wawancara dengan Human Resource Development (HRD) Hotel Kumala Pantai Legian, ditemukan bahwa adanya turnover pada karyawan tetap Hotel Kumala Pantai Legian pada periode 3 tahun terakhir (2015-2017) yang disajikan dalam Tabel 1.

Tabel 1.

Data Turnover Karyawan Tetap Hotel Kumala Pantai Legian

\begin{tabular}{ccccccc}
\hline Tahun & $\begin{array}{c}\text { Jumlah } \\
\text { karyawan } \\
\text { (orang) }\end{array}$ & $\begin{array}{c}\text { Karyawan } \\
\text { masuk } \\
\text { (orang) }\end{array}$ & $\begin{array}{c}\text { Karyawan } \\
\text { masuk (\%) }\end{array}$ & $\begin{array}{c}\text { Karyawan } \\
\text { keluar } \\
\text { (orang) }\end{array}$ & $\begin{array}{c}\text { Karyawan } \\
\text { keluar (\%) }\end{array}$ & $\begin{array}{c}\text { Retensi } \\
\text { (\%) }\end{array}$ \\
\hline 2015 & 164 & 6 & 3,65 & 18 & 10,97 & 89,03 \\
2016 & 152 & 9 & 5,92 & 16 & 10,53 & 89,47 \\
2017 & 145 & 8 & 5,51 & 15 & 10,34 & 89,66 \\
\hline Sumber: HRD Hotel Kumala Pantai Legian, 2018 & & & &
\end{tabular}

Tabel 1. menunjukan bahwa tingkat turnover karyawan tetap pada Hotel Kumala Pantai Legian dari tahun 2015 hingga 2017 mencapai angka diatas 10\%. Data turnover karyawan tetap Hotel Kumala Pantai Legian menunjukan bahwa 
rata-rata karyawan yang mengundurkan diri adalah 16 orang atau 10,61\% pertahun dan hanya mampu mempertahankan karyawan rata-rata 89,38 per tahun selama periode 2015 hingga 2017. Ridlo (2012) menyatakan bahwa pada umumnya tingkat turnover perusahaan tidak boleh melebihi angka 10\% dalam periode satu tahun, dimana hal ini akan menjadikan kinerja perusahaan terganggu.

Kashyap dan Rangnekar (2014) menyatakan bahwa tingginya tingkat turnover pada suatu perusahaan menimbulkan kerugian dalam hal investasi di bidang SDM, untuk itu perusahaan harus bisa mempertahankan karyawan potensialnya agar tingkat retensi karyawan tetap tinggi. Berdasarkan hasil wawancara terhadap 10 orang karyawan tetap Hotel Kumala Pantai Legian, menyatakan bahwa keinginan untuk bertahan pada perusahaan rendah. Hal ini dikarenakan karyawan masih merasa belum mendapatkan peluang karir yang sama, dimana perusahaan kurang memberikan pendidikan dan pelatihan bagi karyawan untuk peningkatan kinerja dan promosi karyawan. Selain itu karyawan juga merasakan kurangnya penghargaan yang diberikan perusahaan, hal ini dapat dilihat dari pemberian insentif yang kurang sesuai dengan jam kerja tambahan yang diberikan. Hubungan antar karyawan pada perusahaan juga dirasa masih kurang baik, hal ini terutama terjadi pada hubungan atasan dengan bawahan yang masih terjadi kesenjangan. Hasil wawancara tersebut dapat mengindikasikan rendahnya retensi karyawan pada Hotel Kumala Pantai Legian.

Rendahnya tingkat retensi karyawan pada Hotel Kumala Pantai Legian disebabkan oleh adanya lingkungan kerja non fisik yang kurang baik yang dirasakan oleh karyawan. Hal ini dapat dilihat dari adanya karyawan yang merasa 
bahwa perusahaan belum mampu menyusun prosedur kerja secara baik, dimana masih terdapat jam kerja tambahan yang tidak terjadwal untuk karyawan. Selain itu, rendahnya keterlibatan organisasional yang dimiliki karyawan menjadi salah satu penyebab rendahnya retensi karyawan pada Hotel Kumala Pantai Legian. Hal ini dikarenakan masih terdapat karyawan yang merasa tidak memiliki komitmen untuk tetap berada pada perusahaan ketika perusahaan berada dalam kondisi yang sulit.

Novliadi (2006) menyatakan bahwa komponen utama dari teori pertukaran sosial yang melibatkan dukungan organisasional adalah hukum timbal balik, dimana ketika seseorang diperlakukan dengan baik oleh orang lain maka timbul kewajiban bagi orang tersebut untuk membalasnya dengan perlakuan baik pula. Teori pertukaran sosial menyatakan bahwa karyawan akan cenderung bertahan pada perusahaan ketika perusahaan tersebut memiliki lingkungan kerja non fisik yang baik (Kundu dan Lata, 2017). Menurut Saks (2006) teori pertukaran sosial mengemukakan bahwa karyawan yang memiliki keterlibatan organisasional yang tinggi, mampu memberikan intensi yang positif untuk bertahan pada perushaan.

Retensi karyawan adalah kemampuan organisasi untuk mempertahankan karyawan yang memiliki kontribusi menguntungkan untuk organisasi Cahyadi dan Utama (2018). Menurut Balta (2014), retensi karyawan merupakan kemampuan perusahaan dalam menjaga karyawan berharga dengan cara menciptakan dan memelihara lingkungan kerja yang mendukung, serta mendorong karyawan untuk tinggal bersama di dalam perusahaan dalam jangka waktu yang lama. Sandhya dan Kumar (2014), mendefinisikan retensi karyawan sebagai upaya sistematis yang 
dilakukan perusahaan untuk menciptakan dan mengembangkan lingkungan yang mendorong karyawan saat ini untuk tetap bersama organisasi.

Sumarni (2011) menyatakan bahwa retensi karyawan adalah suatu kemampuan yang digunakan perusahaan untuk mempertahankan karyawan yang memiliki potensi agar tetap loyal. Menurut Luthans (2008) retensi karyawan merupakan proses dimana karyawan didorong untuk tetap bersama perusahaan dalam periode waktu tertentu atau sampai diselesaikannya suatu pekerjaan. Pratiwi dan Sriathi (2017) mendefinisikan retensi karyawan sebagai upaya yang dilakukan oleh perusahaan untuk mempertahankan loyalitas karyawan yang memiliki kinerja baik dalam perusahaan. Karthi dan Devi (2012) menyatakan bahwa retensi karyawan merupakan suatu proses dimana karyawan didorong agar tetap berada di dalam organisasi untuk jangka waktu maksimum sampai terselesaikannya proyek.

Retensi karyawan bertujuan untuk mempertahankan karyawan yang memenuhi kriteria dari perusahaan dan membuat karyawan yang berkualitas tetap bertahan pada perusahaan (Hafanti dkk., 2015). Menurut Mahalakshmi dan Rao (2012), retensi karyawan dikatakan efektif apabila pemimpin perusahaan melakukan upaya secara sistematis untuk menciptakan lingkungan yang mampu memenuhi kebutuhan karyawan yang beragam, sehingga mendorong karyawan untuk tetap bekerja pada perusahaan. Retensi karyawan akan lebih mudah tercapai jika karyawan memiliki rasa bangga terhadap pekerjaan yang dilakukan di perusahaan tempatnya bekerja (Nwokocha dan Iheriohanma, 2012).

Penelitian yang dilakukan oleh Akila (2012), menyatakan bahwa lingkungan kerja non fisik memiliki pengaruh positif terhadap retensi karyawan. Edwin (2012) 
menemukan bahwa lingkungan kerja non fisik telah menjadi faktor yang lebih efektif dari faktor lainnya dalam menjaga retensi karyawan karena jika karyawan memiliki pengalaman yang positif dari lingkungan kerja, menyebabkan karyawan tersebut bertahan lebih lama pada perusahaan. Pendapat tersebut didukung oleh penelitian yang dilakukan oleh Pratiwi dan Sriathi (2017), yang menyatakan bahwa lingkungan kerja non fisik berpangurh positif dan signifikan terhadap retensi karyawan.

Penelitan yang dilakukan oleh Agarwal (2016), menyatakan bahwa organisasi yang mampu menyediakan lingkungan kerja non fisik yang sesuai dengan tingkat privasi dan kontrol suara karyawan, memiliki kesempatan yang sangat baik untuk mempertahankan karyawan pada organisasi. Ramlall (2003) menyatakan bahwa adanya kondisi lingkungan kerja non fisik yang tidak efektif pada perusahaan mampu diidentifikasikan sebagai alasan mengapa karyawan meninggalkan perusahaan. Kwenin (2013) juga menemukan bahwa lingkungan kerja non fisik berpengaruh positif dan signifikan terhadap retensi karyawan. Berdasarkan uraian di atas, dapat dirumuskaan hipotesis sebagai berikut :

$\mathrm{H}_{1}$ : Lingkungan kerja non fisik berpengaruh positif dan signifikan terhadap retensi karyawan.

Penelitian yang dilakukan oleh Lockwood (2007) menyatakan bahwa keterlibatan organisasional memiliki pengaruh poistif terhadap retensi karyawan. Tingginya keterlibatan pada suatu organisasi, menyebabkan timbulnya motivasi karyawan untuk tetap berada dalam organisasi, dan sebaliknya jika keterlibatan rendah maka menyebabkan tinggnya turnover intention pada perusahaan (de Lange 
et al., 2008). Mathieu et al. (2016) berpendapat bahwa keterlibatan memiliki pengaruh yang positif dan signifikan terhadap retensi karyawan.

Saks (2006) dalam penelitiannya menyatakan bahwa keterlibatan organisasional secara khusus mampu memprediksi retensi karyawan. Nutov dan Hazzan (2014) menyatakan bahwa keterlibatan organisasional yang dimiliki seorang karyawan mampu meningkatkan retensi pada organisasi. Pendapat tersebut diperkuat oleh penelitian Kundu dan Lata (2017) yang menemukan bahwa keterlibatan organisasional berpengaruh positif dan signifikan terhadap retensi karyawan. berikut :

$\mathrm{H}_{2}$ : Keterlibatan organisasional berpengaruh positif dan signifikan terhadap retensi karyawan.

\section{METODE PENELITIAN}

Penelitian ini berlokasi di Hotel Kumala pantai Legian yang beralamat di Jalan Werkudara, Legian, Kuta, Badung-Bali. Alasan dilakukannya penelitian di Hotel Kumala Pantai Legian karena ditemukan masalah-masalah mengenai retensi karyawan, dimana diduga tingkat retensi karyawan dipengaruhi oleh lingkungan kerja non fisik dan keterlibatan organisasional, selain itu pemilihan lokasi tersebut juga dikarenakan tersedianya data yang memadai dan mampu untuk diolah.

Populasi dalam penelitian ini adalah seluruh karyawan tetap Hotel Kumala Pantai Legian yang berjumlah 148 orang. Data jumlah karyawan tetap Hotel Kumala Pantai Legian Tahun 2018 ditunjukan pada Tabel 2 sebagai berikut: 
Tabel 2.

Data Jumlah Karyawan Tetap Hotel Kumala Pantai Legian

\begin{tabular}{clc}
\hline NO & \multicolumn{1}{c}{$\begin{array}{c}\text { Department/Bagian } \\
\text { Jumlah Karyawan } \\
\text { (orang) }\end{array}$} \\
\hline 1. & Human Resources Development Manager & 1 \\
2. & Financial Controller Manager & 1 \\
3. & Supervisor & 12 \\
4. & Assistant Supervisor & 16 \\
5. & Staff & 7 \\
6. & Front Office & 11 \\
7. & Marketing & 1 \\
8. & Bar & 14 \\
9. & Kitchen & 27 \\
10. & House Keeping & 21 \\
11. & Enggineering & 10 \\
12. & Pool and Garden & 10 \\
13. & Security & 9 \\
14. & Spa & 8 \\
& Total & $\mathbf{1 4 8}$ \\
\hline
\end{tabular}

Sumber: HRD Hotel Kumala Pantai Legian, 2018

Jumlah sampel yang diambil dalam penelitian ini menggunakan rumus Slovin. Penggunaan rumus Slovin karena peneliti hanya membutuhkan sampel untuk mewakili dari seluruh populasi, adapun rumus Slovin yaitu sebagai berikut :

$$
n=\frac{\mathrm{N}}{N \cdot d^{2}+1}
$$

Keterangan:

$$
\begin{aligned}
& n=\text { Jumlah sampel } \\
& \mathrm{N}=\text { Jumlah populasi } \\
& \mathrm{d}=\text { Persentase kelonggaran kesalahan pengambilan sampel yang masih } \\
& \\
& \text { dapat ditolerir, dalam penelitian ini digunakan persentase kesalahan } \\
& \quad 5 \% .
\end{aligned}
$$

Jumlah populasi Hotel Kumala Pantai Legian yaitu sebesar 148. Jadi besarnya sampel yang harus dicapai dalam penelitian ini adalah sebesar :

$$
\begin{gathered}
n=\frac{148}{148 \cdot 0,05^{2}+1} \\
n=108,02
\end{gathered}
$$


Berdasarkan rumus Slovin di atas, sampel yang dapat diambil dari populasi yaitu sebanyak 108,02, karena sampel dalam penelitian ini adalah karyawan maka jumlah sampel dibulatkan menjadi 108 responden.

Penelitian ini menggunakan metode analisis regresi linear berganda untuk menjelaskan pengaruh variabel bebas (independen) terhadap variabel terikat (dependen). Variabel bebas (independen) merupakan variabel yang mempengaruhi dalam penelitian ini yaitu variabel lingkungan kerja non fisik $\left(\mathrm{X}_{1}\right)$ dan keterlibatan organisasional $\left(\mathrm{X}_{2}\right)$, sedangkan variabel terikat (dependen) merupakan variabel yang dipengaruhi dalam penelitian ini adalah retensi karyawan (Y). Adapun model regresi linear berganda yang dapat dijabarkan dengan menggunakan persamaan sebagai berikut:

$$
\mathrm{Y}=\alpha+\beta_{1} \mathrm{X}_{1}+\beta_{2} \mathrm{X}_{2}+\mathrm{e}
$$

Keterangan:

$\begin{array}{ll}\alpha & =\text { Konstanta } \\ \beta_{1} \beta_{2} & =\text { Koefisien regresi } \\ \mathrm{Y} & =\text { Retensi Karyawan } \\ \mathrm{X}_{1} & =\text { Lingkungan Kerja Non Fisik } \\ \mathrm{X}_{2} & =\text { Keterlibatan Orgnisasional } \\ \mathrm{e} & =\text { Error }\end{array}$

Pengaruh variabel bebas (independen) terhadap variabel terikat (dependen) diuji dengan tingkat kepercayaan (Convidence interval) 95\% atau $\alpha=5 \%$.

\section{HASIL DAN PEMBAHASAN}

Data karakteristik responden pada penelitian ini diperoleh dari profil responden yang terdapat dalam kuisioner yang telah disebarkan. Berdasarkan hasil penelitian yang dilakukan pada karyawan tetap Hotel Kumala Pantai Legian, dapat 
diketahui karakteristik responden meliputi umur, jenis kelamin, tingkat pendidikan dan masa kerja yang dapat dilihat pada Tabel 3.

Tabel 3.

Karakteristik Responden Hotel Kumala Pantai Legian

\begin{tabular}{|c|c|c|c|}
\hline No & Karakteristik & Jumlah (orang) & Persentase (\%) \\
\hline \multirow[t]{6}{*}{1} & Umur & & \\
\hline & 21 - 30 Tahun & 29 & 26,9 \\
\hline & 31 - 40 Tahun & 53 & 49,1 \\
\hline & 41 - 50 Tahun & 25 & 23,1 \\
\hline & $>50$ Tahun & 1 & 0,9 \\
\hline & Total & 108 & 100 \\
\hline \multirow[t]{4}{*}{2} & Jenis Kelamin & & \\
\hline & Laki-laki & 82 & 75,9 \\
\hline & Perempuan & 26 & 24,1 \\
\hline & Total & 108 & 100 \\
\hline \multirow[t]{6}{*}{3} & Tingkat Pendidikan & & \\
\hline & SMA/SMK & 55 & 51,0 \\
\hline & Diploma & 27 & 25,0 \\
\hline & S1 & 25 & 23,1 \\
\hline & S3 & 1 & 0,9 \\
\hline & Total & 108 & 100 \\
\hline \multirow[t]{5}{*}{4} & Masa Kerja & & \\
\hline & $<5$ Tahun & 43 & 39,8 \\
\hline & 5 - 10 Tahun & 45 & 41,7 \\
\hline & $>10$ Tahun & 20 & 18,5 \\
\hline & Total & 108 & 100 \\
\hline
\end{tabular}

Sumber: Data diolah, 2018

Tabel 3 menunjukan bahwa karyawan tetap Hotel Kumala Pantai Legian sebagian besar berumur 31 hingga 40 tahun dengan jumlah 53 responden atau berkisar 49,1 persen. Hal ini menunjukan bahwa karyawan tetap Hotel Kumala Pantai Legian berada pada usia produktif sehingga dapat memberikan kontribusi yang baik untuk perusahaan. Responden yang berjenis kelamin laki-laki berjumlah 82 responden atau 75,9 persen, dan responden yang berjenis kelamin perempuan berjumlah 26 responden atau 24,1 persen. Hal ini menunjukan bahwa responden laki-laki lebih dominan dibandingkan responden perempuan. Responden yang memiliki tingkat pendidikan SMA/SMK mendominasi dengan jumlah 55 responden atau 51 persen dibandingkan responden dengan tingkat pendidikan 
Diploma, S1 dan S3. Hal ini dikarenakan pekerjaan yang terdapat di perusahaan lebih banyak membutuhkan skill dalam setiap bidangnya. Responden yang memiliki masa kerja 5 sampai 10 tahun mendominasi dengan jumlah 45 responden atau 41,7 persen. Hal ini menunjukan bahwa karyawan tetap Hotel Kumala Pantai Legian memiliki masa kerja yang tidak terlalu lama.

Instrumen dikatakan valid apabila korelasi antara skor faktor dengan skor total bernilai positif dan nilainya lebih dari 0,3 $(r>0,3)$. Hasil uji validitas disajikan pada Tabel 4 sebagai berikut :

Tabel 4.

Hasil Uji Validitas

\begin{tabular}{cccc}
\hline Variabel & Indikator & Koefisien Korelasi & Keterangan \\
\hline Retensi Karyawan & Y.1 & 0,916 & Valid \\
(Y) & Y.2 & 0,885 & Valid \\
& Y.3 & 0,868 & Valid \\
& X1.1 & 0,881 & Valid \\
Lingkungan Kerja & X1.2 & 0,892 & Valid \\
Non Fisik (X1) & X1.3 & 0,930 & Valid \\
& X1.4 & 0,854 & Valid \\
X1.5 & 0,886 & Valid \\
Keterlibatan Organisasional & X1.6 & 0,674 & Valid \\
(X2) & X2.1 & 0,908 & Valid \\
& X2.3 & 0,924 & Valid \\
& & 0,909 & Valid
\end{tabular}

Sumber: Data diolah, 2018

Tabel 4. menunjukan bahwa hasil uji validitas dari seluruh instrumen penelitian yang digunakan untuk mengukur variabel retensi karyawan lingkungan kerja non fisik dan keterlibatan organisasional memiliki nilai koefisien korelasi dengan skor total seluruh item pernyataan lebih besar dari 0,3 . Hasil uji validitas dari tiga variabel yang diteliti memperoleh nilai koefisien korelasi terkecil yaitu 0,674 dan nilai terbesar yaitu 0,930 . Hal ini menunjukan bahwa butir-butir pernyataan dalam instrument penelitian tersebut valid dan layak digunakan sebagai instrument penelitian. 
Instrumen dikatakan reliabel jika instrumen tersebut memiliki nilai cronbach's alpha lebih dari 0,60. Hasil uji reliabilitas disajikan dalam Tabel 5 sebagai berikut:

Tabel 5.

Hasil Uji Reliabilitas

\begin{tabular}{ccc}
\hline Variabel & Cronbach's Alpha & Keterangan \\
\hline Retensi Karyawan $(\mathrm{Y})$ & 0,864 & Reliabel \\
Lingkungan Kerja Non Fisik $\left(\mathrm{X}_{1}\right)$ & 0,919 & Reliabel \\
Keterlibatan Organisasional $\left(\mathrm{X}_{2}\right)$ & 0,895 & Reliabel \\
\hline
\end{tabular}
Sumber: Data diolah, 2018

Tabel 5. menunjukan bahwa semua variabel memiliki nilai cronbach's alpha lebih dari 0,60 . Hal ini menunjukan bahwa seluruh instrumen penelitian yang digunakan untuk mengukur variabel retensi karyawan lingkungan kerja non fisik dan keterlibatan organisasional dapat dikatakan reliabel dan layak digunakan untuk melakukan penelitian.

Metode regresi linear berganda digunakan dalam penelitian ini untuk mengetahui pengaruh lingkungan kerja non fisik (X1), keterlibatan organisasional (X2) terhadap retensi karyawan (Y). Metode ini menggunakan sistem berupa SPSS.21 For Windows, maka diperoleh hasil seperti Tabel 6 berikut:

Tabel 6.

Hasil Analisis Regresi Linear Berganda

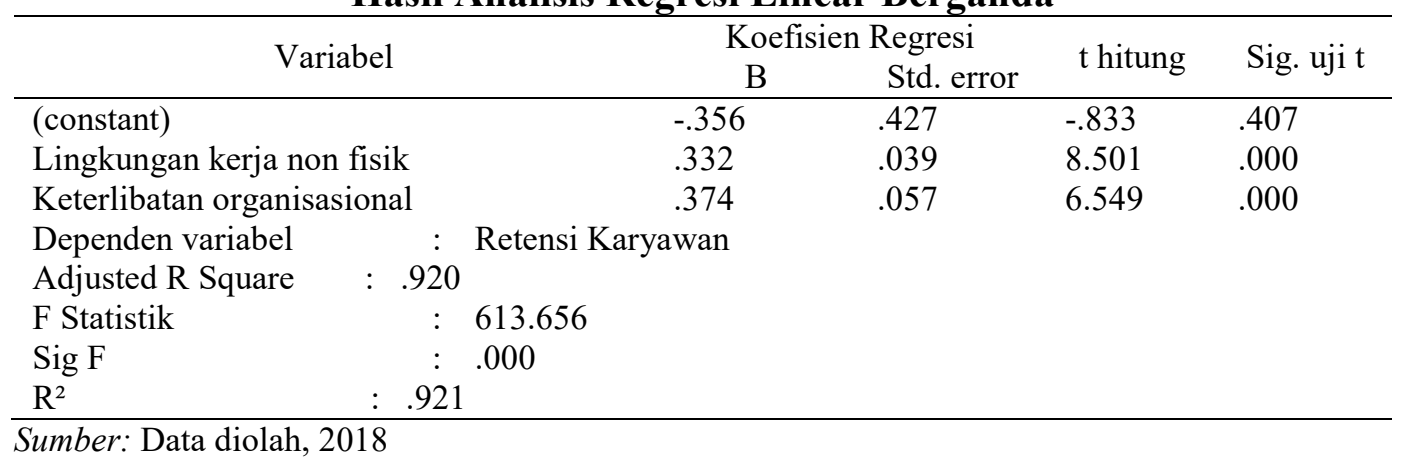

Berdasarkan Tabel 6. diperoleh persamaan regresi linear berganda sebagai berikut : 


$$
\mathrm{Y}=-0,356+0,332 \mathrm{X} 1+0,374 \mathrm{X} 2+\mathrm{e}
$$

Keterangan :

$$
\begin{array}{ll}
\mathrm{Y} & =\text { Retensi Karyawan } \\
\mathrm{X}_{1} & =\text { Lingkungan Kerja Non Fisik } \\
\mathrm{X}_{2} & =\text { Keterlibatan Organisasional } \\
\mathrm{e} & =\text { Error }
\end{array}
$$

Nilai koefisien $\beta_{1}$ sebesar 0,332 berarti bahwa terdapat pengaruh positif dan signifikan antara lingkungan kerja non fisik terhadap retensi karyawan. Hal ini berarti semakin baik lingkungan kerja yang diciptakan suatu perusahaan maka retensi karyawan pada perusahaan akan semakin meningkat.

Nilai koefisien $\beta_{2}$ sebesar 0,374 berarti bahwa terdapat pengaruh positif dan signifikan antara keterlibatan organisasional terhadap retensi karyawan. Hal ini berarti semakin tinggi keterlibatan organisasional yang dimiliki seorang karyawan akan meningkatkan retensi karyawan pada perusahaan.

Pengujian kefisien determinasi $\left(\mathrm{R}^{2}\right)$ digunakan untuk mengukur presentase kemampuan semua variabel bebas dalam menerangkan variasi dari variabel terikat. Koefisien determinasi berkisar antara nol sampai satu $\left(0 \leq \mathrm{R}^{2} \leq 1\right)$. Jika $\mathrm{R}^{2}$ semakin besar (mendekati satu), maka dapat dikatakan bahwa pengaruh variabel bebas adalah besar terhadap variabel terikat. Hal ini berarti model yang digunakan

\begin{tabular}{|c|c|c|c|c|}
\hline Model & $\mathbf{R}$ & R Square & $\begin{array}{l}\text { Adjusted R } \\
\text { Square }\end{array}$ & $\begin{array}{l}\text { Std. Error of } \\
\text { the Estimate }\end{array}$ \\
\hline 1 & $.960^{\mathrm{b}}$ & .921 & .920 & .562 \\
\hline
\end{tabular}
semakin kuat untuk menerangkan pengaruh variabel bebas terhadap variabel terikat. Hasil uji koefisien determinasi $\left(\mathrm{R}^{2}\right)$ disajikan pada Tabel 7 sebagai berikut:

Tabel 7.

\section{Hasil Uji Koefisien Determinasi $\left(\mathbf{R}^{\mathbf{2}}\right)$}


Berdasarkan hasil uji koefisien determinasi $\left(\mathrm{R}^{2}\right)$ pada Tabel 7 diperoleh nilai $\mathrm{R}^{2}$ sebesar 0,921 yang artinya sebesar 92,1 persen variasi retensi karyawan dijelaskan oleh lingkungan kerja non fisik dan keterlibatan organisasional, sedangkan sisanya sebesar 7,9 persen dipengaruhi oleh faktor-faktor lain yang tidak dimasukan ke dalam model penelitian.

Uji kelayakan model atau Uji F digunakan untuk menunjukan kelayakan model regresi linear berganda sebagai alat analisis yang menguji pengaruh variabel bebas secara bersama (simultan) terhadap variabel terikat. Uji F dilakukan dengan melihat nilai signifikansi pada Tabel anova. Jika signifikansi $<0,05$ maka model analisis dianggap layak dan jika signifikansi $>0,05$ maka model analisis dianggap tidak layak. Hasil uji F disajikan pada Tabel 8 sebagai berikut :

Tabel 8.

\section{Hasil Uji F}

\begin{tabular}{|c|c|c|c|c|c|c|}
\hline & Model & $\begin{array}{l}\text { Sum of } \\
\text { Squares }\end{array}$ & $\mathrm{Df}$ & Mean Square & $\mathrm{F}$ & Sig. \\
\hline \multirow{3}{*}{1} & Regresion & 387.198 & 2 & 193.599 & 613.656 & $.000^{\mathrm{a}}$ \\
\hline & Residual & 33.125 & 105 & .315 & & \\
\hline & Total & 420.234 & 107 & & & \\
\hline
\end{tabular}

Sumber: Data diolah, 2018

Berdasarkan hasil uji $\mathrm{F}$ pada Tabel 8. diperoleh nilai signifikansi $\mathrm{F}$ atau $p$ value sebesar 0,000 yang berarti lebih kecil dari $0,05(\mathrm{~F}<\alpha)$. Hal ini menunjukan bahwa variabel bebas yaitu lingkungan kerja non fisik dan keterlibatan organisasional berpengaruh positif dan signifikan terhadap variabel terikat yaitu retensi karyawan atau model regresi yang digunakan layak uji.

Berdasarkan Tabel 6. diperoleh nilai signifikansi uji t untuk variabel lingkungan kerja non fisik sebesar 0,000 yang berarti lebih kecil dari 0,05 dengan nilai koefisien regresi sebesar 0,332. Hal ini menunjukan bahwa lingkungan kerja 
non fisik berpengaruh positif dan signifikan terhadap retensi karyawan, oleh karena itu hipotesis pertama dapat diterima.

Berdasarkan Tabel 6. diperoleh nilai signifikansi uji t untuk variabel keterlibatan organisasional sebesar 0,000 yang berarti lebih kecil dari 0,05 dengan nilai koefisien regresi sebesar 0,374 . Hal ini menunjukan bahwa keterlibatan organisasional berpengaruh positif dan signifikan terhadap retensi karyawan, oleh karena itu hipotesis kedua dapat diterima.

Hasil pengujian hipotesis penelitian ini menunjukan lingkungan kerja non fisik berpengaruh positif dan signifikan terhadap retensi karyawan. Hal ini berarti bahwa hipotesis pertama pada penelitian ini yaitu lingkungan kerja non fisik berpengaruh positif dan signifikan terhadap retensi karyawan, dapat diterima. Berdasarkan hasil deskripsi variabel penelitian mengenai lingkungan kerja non fisik, terdapat empat indikator yang memiliki nilai rata-rata diatas rata-rata varibel. Pertama terdapat pada indikator kejelasan tugas dengan pernyataan "Saya mampu melaksanakan pekerjaan berdasarkan instruksi dari atasan $\left(\mathrm{X}_{1.4}\right)$ ", kedua pada indikator hubungan antar karyawan dengan pernyataan "Hubungan antar karyawan berjalan harmonis $\left(\mathrm{X}_{1.6}\right)$ ", ketiga pada indikator prosedur kerja dengan pernyataan "Saya bekerja sesuai dengan prosedur kerja yang telah diatur secara berurutan $\left(\mathrm{X}_{1.1}\right)$ " dan yang keempat pada indikator standar kerja dengan pernyataan "Saya bekerja sesuai standar kerja yang diberikan agar mencapai tujuan perusahaan $\left(\mathrm{X}_{1.2}\right)$.

Hal ini berarti bahwa karyawan merasa mampu bekerja sesuai dengan instruksi dari atasan, prosedur kerja yang berurutan, standar kerja yang digunakan 
untuk mencapai tujuan perusahaan serta merasa didukung dengan adanya hubungan harmonis yang terjalin antar rekan kerja dalam melakukan pekerjaan di perusahaan, dimana hal ini akan menimbulkan rasa nyaman bagi karyawan untuk bekerja di dalam perusahaan sehingga dapat meningkatkan retensi karyawan pada Hotel Kumala Pantai Legian. Hasil penelitian ini didukung oleh penelitian yang dilakukan oleh Akila (2012) yang menyatakan bahwa lingkungan kerja non fisik memiliki pengaruh positif terhadap retensi karyawan. Penelitian yang dilakukan oleh Pratiwi dan Sriathi (2017) juga menyatakan bahwa lingkungan kerja non fisik berpengaruh positif dan signifikan terhadap retensi karyawan. Selain itu penelitian yang dilakukan oleh Kwenin (2013) menemukan bahwa lingkungan kerja non fisik memiliki pengaruh positif dan signifikan terhadap retensi karyawan.

Hasil pengujian hipotesis penelitian ini menunjukan keterlibatan organisasional berpengaruh positif dan signifikan terhadap retensi karyawan. Hal ini berarti bahwa hipotesis kedua pada penelitian ini yaitu keterlibatan organisasional berpengaruh positif dan signifikan terhadap retensi karyawan, dapat diterima. Berdasarkan hasil deskripsi variabel penelitian mengenai keterlibatan organisasional, terdapat dua indikator dengan nilai rata-rata diatas rata-rata variabel. Pertama tedapat pada indikator praise (pujian) dengan pernyataan "Saya memberi tahu orang lain betapa bangganya saya bekerja untuk perusahaan ini $\left(\mathrm{X}_{2.1}\right)$ ", kedua terdapat pada indikator perform (kinerja) dengan pernyataan "Cara perusahaan dalam menjalankan bisnisnya sehari-hari, menginspirasi saya untuk melakukan semua hal demi memastikan keberhasilan perusahaan $\left(\mathrm{X}_{2.2}\right)$ ". Hal ini berarti besarnya kesediaan karyawan dalam mempromosikan rasa bangganya 
terhadap perusahaan kepada orang lain serta banyaknya karyawan yang merasa terinspirasi akan cara perusahaan menjalankan bisnisnya sehari-hari akan menimbulkan tindakan-tindakan karyawan yang dapat membantu perusahaan dalam mencapai keberhasilan, dimana hal ini mengindikasikan tingginya keinginan karyawan untuk bertahan pada perusahaan sehingga dapat meningkatkan retensi karyawan pada Hotel Kumala Pantai Legian.

Hasil penelitian ini didukung oleh penelitian yang dilakukan oleh Loockwood (2007) yang menyatakan bahwa keterlibatan organisasional memiliki pengaruh poistif terhadap retensi karyawan. Penelitian yang dilakukan oleh Mathieu et al. (2016) juga menemukan bahwa terdapat pengaruh yang positif dan signifikan antara keterlibatan organisasional terhadap retensi karyawan. Selain itu, penelitian yang dilakukan oleh Kundu dan Lata (2017) menyatakan bahwa keterlibatan organisasional berpengaruh positif dan signifikan terhadap retensi karyawan.

Hasil penelitian ini dapat memberikan informasi kepada Hotel Kumala Pantai Legian dalam rangka meningkatkan retensi karyawan. Berdasarkan hasil penelitian, menunjukan bahwa lingkungan kerja non fisik berpengaruh positif dan signifikan terhadap retensi karyawan. Hal ini berarti semakin baik lingkungan kerja non fisik yang mampu diberikan perusahaan, maka karyawan akan merasa nyaman dalam bekerja sehingga retensi karyawan pada Hotel Kumala Pantai Legian semakin tinggi.

Hasil penelitian yang kedua menunjukan bahwa keterlibatan organisasional berpengaruh positif dan signifikan terhadap retensi karyawan. Hal ini menunjukan bahwa ketika karyawan Hotel Kumala Pantai Legian memiliki keterlibatan 
organisasional yang tinggi, maka karyawan tersebut memberikan kinerja yang maksimal dan dampak yang positif bagi perusahaan perusahaan. Hasil kinerja maksimal yang diberikan karyawan memudahkan perusahaan dalam memberikan timbal balik yang setimpal berupa peluang karir, penghargaan serta tindakan yang baik bagi karyawan, sehingga retensi karyawan pada Hotel Kumala Pantai Legian semakin baik.

\section{SIMPULAN DAN SARAN}

Lingkungan kerja non fisik berpengaruh positif dan signifikan terhadap retensi karyawan pada Hotel Kumala Pantai Legian. Hal ini menunjukan bahwa semakin baik lingkungan kerja non fisik yang dirasakan oleh karyawan, maka besar keinginan karyawan untuk bertahan pada perusahaan sehingga retensi karyawan semakin tinggi. Keterlibatan organisasional berpengaruh positif dan signifikan terhadap retensi karyawan. Hal ini menunjukan bahwa semakin tinggi keterlibatan organisasional yang dimiliki oleh karyawan, maka semakin besar keinginan karyawan untuk bertahan pada perusahaan sehingga retensi karyawan semakin tinggi.

Secara teoritis saran yang dapat diberikan untuk meningkatkan retensi karyawan, variabel lingkungan kerja non fisik dan keterlibatan organisasional perlu diperhatikan. Hal ini berarti bahwa ketika lingkungan kerja non fisik yang dirasakan oleh karyawan semakin baik, maka retensi karyawan akan semakin tinggi, sedangkan ketika karyawan memiliki keterlibatan organisasional yang tinggi, maka hal ini dapat menjaga tingginya tingkat retensi karyawan. 
Secara praktis saran yang dapat diberikan untuk meningkatkan retensi karyawan pada Hotel Kumala Pantai Legian yaitu perusahaan perlu lebih memperhatikan sistem penghargaan yang digunakan untuk mengenali prestasi masing-masing karyawan serta memperhatikan penyusunan tugas karyawan agar pekerjaan dapat dilakukan secara adil, hal ini dikarenakan indikator sistem penghargaan dengan pernyataan "Perusahaan memberikan penghargaan untuk mengenali prestasi karyawan $\left(\mathrm{X}_{1.5}\right)$ " dan indikator pertanggungjawaban supervisor dengan pernyataan "Perusahaan menyusun tugas karyawan agar pekerjaan dapat dikerjakan secara secara adil $\left(\mathrm{X}_{1.3}\right)$ " memiliki nilai rata-rata dibawah rata-rata variabel pada deskripsi variabel penelitian tentang lingkungan kerja non fisik. Pemberian penghargaan perlu dilakukan secara lebih adil agar perusahaan dapat mengenali prestasi karyawan dan penyusunan tugas karyawan perlu dilakukan secara adil agar karyawan merasa nyaman dan termotivasi untuk bekerja dengan lebih baik sehingga retensi karyawan dapat ditingkatkan. Selain itu perusahaan juga perlu memeperhatikan kemampuan karyawan dalam bertahan pada perusahaan, karena indikator persist (ketahanan) dengan pernyataan "Saya mengidentifikasi visi perusahaan ini untuk tetap berkomitmen meskipun berada dalam kondisi yang sulit $\left(\mathrm{X}_{2.3}\right)$ " memiliki nilai rata-rata dibawah rata-rata varibel pada deskripsi variabel penelitian tentang keterlibatan organisasional. Perusahaan perlu meningkatkan kemampuan karyawan dalam mengidentifikasi atau menetapkan visi perusahaan sebagai alasan untuk tetap bertahan pada perusahaan sehingga dapat meningkatkan retensi karyawan. 
Desak Made Yuni Astuti, Pengaruh Lingkungan Kerja....

Saran yang dapat diberikan untuk penelitian selanjutnya yaitu karena penelitian ini hanya meneliti tentang pengaruh lingkungan kerja non fisik dan keterlibatan organisasional terhadap retensi karyawan, maka penelitian selanjutnya diharapkan dapat mempertimbangkan faktor lain yang dapat mempengaruhi retensi karyawan seperti stres kerja, komitmen organisasional atau keadilan organisasional. Selain itu, penelitian selanjutnya diharapkan dapat menggunakan teknik analisis lain seperti analisis SEM atau analisis path serta memperluas ruang lingkup pengambilan sampel seperti industri perbankan maupun industri manufaktur. Penelitian selanjutnya diharapkan mampu memberikan hasil yang bervariasi yang dapat memperkaya referensi mengenai retensi karyawan, lingkungan kerja non fisik dan keterlibatan organisasional.

\section{REFERENSI}

Agarwal, U.A. (2016). Examining Perceived Organizational Politics Among Indian Managers: Enggagement as Mediator and Locus of Control as Mediator. International Journal of Organizational Analysis, 24 (3). 415-437.

Ahmed, Shaheen and Md Nokir Uddin. (2012). Job Satisfaction of Bankers and its Impact in Banking: A Case Study of Janata Bank. Journal ASA University Review, 6 (2). 95-102.

Akila. (2012). A Study on Employee Retention Among Executives at BGR Energy Systems I.TD, Chennai. International Journal of Marketing, Financial Services and Management Research, 1 (9). 18-32.

Astuti, Diah Puji dan Mutiara Sibarani Panggabean. (2014). Pengaruh Kompensasi Terhadap Retensi Karyawan Melalui Kepuasan Kerja dan Komitmen Afektif pada Beberapa Rumah Sakit di DKI Jakarta. Jurnal Manajemen dan Pemasaran Jasa, 7 (1). 199-217.

Balta, M. (2014). Employee retention. In : International Human Resource Management. Melbourne, Australia: Cambridge University Press.

Blau, P.M. (1964). Exchange and Power in Social Life, New York: Transaction Publishers.

Cahyadi, Meliana Kurniawati dan I Wayan Mudiartha Utama. (2018). Pengaruh Iklim Organisasi Terhadap Komitmen Organisasional dan Retensi Pegawai 
Kontrak di Bappeda Litbang Provinsi Bali. E-Jurnal Manajemen Unud, 7 (10). 5508-5538.

Cao, Zhoutgo., Jinxi Chen and Yixiao Song. (2013). Does Total Reward Reduce The Core Employees Turnover Intention. International Journal of Business and Management, 8 (20). 62-75.

Darmawati, Arum., Lina Nur Hidayati dan Dyna Herlina S. (2013). Pengaruh Kepuasan Kerja dan Komitmen Organisasi Terhadap Organizational Citizenship Behavior. Jurnal Ekonomika, 9 (1). 10-17.

Das, Bidisha Lahkar and Mukulesh Baruah. (2013). Employee Retention: A Riview of Literature. IOSF Journal of Business and Management (IOSR-JBM), 14 (2). 08-16.

de Lange, A.H., Hans De Witte and Guy Notelaers. (2008). Should I Stay or Should I Go? Examining Longitudinal Relations Among Job Resources and Work Engagement for Stayers Versus Movers. Work and Stress, 22 (3). 201-223.

Dess, G. G. and J. D. Shaw. (2001). Voluntary Turnover, Social Capital, and Organizational Performance. Academy of Management Review, 26 (3). 446456.

Edwin. (2012). Analisis Pengaruh Lingkungan Kerja dan Kompensasi Terhadap Kepuasan Kerja serta Dampaknya Terhadap Retensi Karyawan Pada PT Lion Wings. hal. 1-31.

Fatima. (2011). Does Employee Retention Affect Organizational Competence. Industrial Engineering Letters. Industrial Engineering Letters, 1 (1). 24-39.

Fung, N. S., A. Ahmad and Z. Omar. (2012). Work-family Enrichment: It's Mediating Role in The Relationship Between Dispositional Factors and Job Satisfaction. International Journal of Social Sciences, 2 (3). 26-37.

Gberevbie, Daniel Esme. (2008). Staff Recruitment, Retention Strategies and Performance of Selected Piblic and Private Organization in Nigeria. Ph.D. Thesis. Collegeof Businessand Social Sciences Covenant University Nigeria.

Ghosh, P., R. Satyawadi., J. Prasad Joshi and Shadman M. (2013). Who Stays With You? Factors Predicting Employees' Intention To Stay. International Journal of Organizational Analysis, 21 (3). 288-312.

Glen, Clyaton. (2006). Key Skills Retention and Motivation: The War for Talent Still Rages and Retention Is The High Ground. Emerald Group Publishing Limited, 38 (1). 37-45.

Hafanti, Oktina., Rahman Lubis dan Hafasnudi. (2015). Pengaruh Kompensasi, lingkungan kerja dan Desain Tugas Terhadap Kepuasan Kerja dan Dampaknya Terhadap Retensi Karyawan Palang Merah Indonesia (PMI) 
Provinsi Aceh. Jurnal Manajemen Pasca Universitas Syiah Kuala, 4 (1). 164-173.

Harter, J.K., Frank L. Schmidt and Theodore L. Hayes. (2002). Business-UnitLevel Relationship Between Employee Satisfaction, Employee Engagement, and Business Outcomes: A Meta-Analysis. Journal of Applied Psychology, 87 (2). 268-279.

Indayati, Nurul., Armanu Thoyib dan Rofiyati. (2012). Pengaruh Keterlibatan Karyawan, Budaya Organisasi dan Gaya Kepemimpinan Terhadap Komitmen Organisasional dalam Meningkatkan Kinerja Karyawan (Studi pada Universitas Brawijaya). Jurnal Aplikasi Manajemen, 10 (2). 344-356.

Jennifer, A Carsen. (2005). HR How To Employee Retention, Chicago: J.D. CCH Incorporated.

Juhdi, N., Fatimah Pa'wan and Ram Milah Kaur Hansaram. (2013). HR Practices and Turnover Intention: The Mediating Roles of Organizational Commitment and Organizational Engagement In A Selected Region In Malaysia. The International Journal of Human Resource Management, 24 (15). 3002-3019.

Kahn, W. A. (1990). Psychological Conditions of Personal Engagement and Disengagement at Work. Academy of Management Journal, 33 (4). $692-$ 724.

Karthi, P. and P. J. Devi. (2012). A Study on Employee Retention In Leading Multional Automobile Sector In India. International Journal of Management Research and Review, 2 (9). 1474-1482.

Kashyap, V. and S. Rangnekar. (2014). A Structural Equation Model for Measuring The Impact of Employee Retention Practices on Employee's Turnover Intentions: An Indian Perspective. South Asian Journal of Human Resources Management, 1 (2). 221-247.

Kundu, Subhash C. and Kusum Lata. (2017). Effects of Supportive Work Environment on Employee Retention: Mediating Role of Organizational Engagement. International Journal of Organizational Analysis, 25 (4). 703 722.

Kwenin, Daisy Ofosuhene. (2013). Relationship Between Work Environment, Career Development Opportunities and Employee Retention In Vodafane Ghana Limited. Journal Of Human Resource Management, 1 (4). 1-9.

Lockwood, R. (2007). Leveraging Employee Engagement For Competitive Advantage: HR's Strategic Role. HR Magazine, 52 (3). 1-11.

Luthans, Fred. (2008). Organizational Behavior. Singapore: McGraw-Hill. 
Mahalakshmi, R. and Ch. Bala Nageswara Rao. (2012). A Study on Effective Employee Rtention Strategis. International Journal of Logistics and Supply Chain Management Perspectives, 1 (1). 18-21.

Malinen, S., Sarah Wright and Peter Cammock. (2013). What Drives Organizational Engagement? A Case Study On Trust, Justice Perceptions And Withdrawal Attitudes. Evidence-based HRM: A Global Forum for Emprical Scholarship, 1 (1). 96-108.

Mathieu, C., W. B. Scaufeli and L. Raymond. (2016). The Role of Supervisory Behavior, Job Satisfaction And Organizational Commitment On Employee Turnover. Journal of Management and Organization, 22 (1). 113-129.

Mustika, I. K. (2012). Analisis Budaya Organisasi dan Kepuasan Kerja Melalui Komitmen Perngaruhnya terhadap Intention to Leave Karyawan pada Industri Jasa Perhotelan di Kabupaten Badung dan Kota Denpasar. Jurnal Mitra Ekonomi dan Manajemen Bisnis, 3 (1). 1-24.

Nitisemito. (2006). Manajemen Sumber Daya Manusia, Edisi Ketiga. Yogyakarta: Ghalia Indonesia.

Novliadi, Ferry. (2006). Organizational Citizenship Behavior Karyawan Ditinjau dari Persepsi Terhadap Kualitas Interaksi Atasan-Bawahan dan Persepsi Terhadap Dukungan Organisasional. PSIKOLOGIA, 2 (1). 39 - 46.

Nutov, L. and Orit Hazzan. (2014). An Organizational Engagement Model As A Management Tool for High School Principals. Journal of Educational Administration, 52 (4). 469-486.

Nwokocha, I. and E. B. J. Iheriohanma. (2012). Emerging Trends In Employee Retention Strategies In A Glovalizing Economy: Nigeria In Focus. Asian Social Science, 8 (10). 198-207.

Pratiwi, Luh Putu Yunia dan Anak Agung Ayu Sriathi. (2017). Pengaruh Lingkungan Kerja dan Pengembangan Karir Terhadap Retensi Karyawan pada Hotel Santika Nusa Dua Bali. E-Jurnal Manajemen Universitas Udayana, 6 (3). 1478-1506.

Putra, Ida Bagus Gede Swambawa dan Agoes Ganesha Rahyuda. (2016). Pengaruh Kompensasi, Lingkungan Kerja dan Perceived Organizational Support (POS) Terhadap Retensi Karyawan. E-Jurnal Manajemen Universitas Udayana, 5 (2). 810-837.

Putra, I Made Wijanu dan I Komang Ardana. (2016). Pengaruh Motivasi Serta Lingkungan Kerja Terhadap Kepuasan Kerja Serta Dampaknya Terhadap Produktivitas Perajin Perak. E-Jurnal Manajemen Universitas Udayana, 5 (12). $7752-7784$ 
Ragupathi. (2013). The Employee Retention Practices of MNC'S in Hyderabad. Research Journal of Management Sciences, 2 (4). 21-24.

Rahmawanti, N.P., B. Swasto, dan A. Prasetya. (2014). Pengaruh Lingkungan Kerja Terhadap Kinerja Karyawan (Studi pada Karyawan Kantor Pelayanan Pajak Pratama Malang Utara). Jurnal Administrasi Bisnis, 8 (2). 1-9.

Ramlall, S. (2003). Managing Employee Retention as a Strategy for Increasing Organizational Competitiveness. Applied H.R.M. Research, 8 (2). 63-72.

Rayadi. (2012). Faktor Sumber Daya Manusia yang Meningkatkan Kinerja Karyawan dan Perusahaan di Kalbar, Jurnal EKSOS. 8 (2). 114-119.

Ridlo, Ilham Akhsanu. (2012). Turnover Karyawan “Kajian Literatur”. Surabaya: PH Movement Publication.

Rothbard, N. P. (2001). Enriching Or Depleting? The Dynamics of Engagement In Work and Family Roles. Administrative Science Quarterly, 46 (4). 655-684.

Saks, A. M. (2006). Antecedents and Consequences of Employee Engagement. Journal of Managerial Psychology, 21 (7). 600-619.

Sandhya, K. and D. Pradeep Kumar. (2014). Employee Retention - A Strategic Tool for Organisational Growth and Sustaining Competitiveness. Journal of Strategic Human Resource Management, 3 (3). 42-45.

Sari, Eliana dan Joni Sinulingga. (2011). Pengaruh Pengembangan Karir dan Kompensasi Terhadap Motivasi Karyawan. Jurnal Ilmiah Penelitian Manajemen Manajerial, 2 (1). 431-440.

Schaufeli, W.B. and Arnold B. Bakker. (2004). Job Demands, Job Resources, and Their Relationship With Burnout and Engagement: A Multi-Sample Study. Journal of Organizational Behavior, 25 (3). 293-315.

Schaufeli, W.B., Marisa Salanova., Vicente Gonzalez-Roma and Arnold B. Bakker. (2002). The Measurement of Engagement and Burnout: A Two Sample Confirmatory Factor Analytic Approach. Journal of Happiness Studies, 3. 71-92.

Sedarmayanti. (2011). Tata Kerja dan Produktivitas Kerja : Suatu Tinjauan dari Aspek Ergonomi Atau Kaitan Antara Manusia dengan Lingkungan Kerjanya. Cetakan Ketiga. Bandung: Mandar Maju.

Sirisunhirun, Somboon and Nopraenue Sajjarax Dhirathiti. (2015). Job Characteristics and a Happy Workplace: Increasing Organisational Engagement in Thai Higher Education Institutions. Organization Development Journal, 33 (1). 73-85.

Sumarni, Murti. (2011). Pengaruh Employee Retention Terhadap Turnover Intention dan Kinerja Karyawan. Jurnal Akuntansi dan Manajemen, 8 (1). 20-47. 
E-Jurnal Manajemen, Vol. 8, No. 7, $2019: 4384-4413$

Supardi. (2003). Kinerja Karyawan. Jakarta: Ghalia.

Susilo, A. (2013). Pengaruh Retensi Karyawan dan Kepuasan Pelanggan Terhadap Kinerja. Jurnal Studi Akuntansi dan Bisnis, 1 (3). 247-262.

Taiwo. (2010). The Influence of Work Environment On Workers Productivity: A Case of Selected Oil and Gas Industry In Lagos, Nigeria. African Journal of Business Management, 4 (3). 299-307.

Widodo. (2014). Influence of Leadership and Work Environment To Job Satisfaction and Impact To Employee Performance (Study On Industrial Manufacture In West Java). Journal of Economics and Sustainable Development, 5 (26). 62-66.

Wursanto, Ignasius. (2009). Dasar-Dasar Ilmu Organisasi, Edisi Kedua. Yogyakarta: Andi. 